\title{
BENTUK KANONIK SMITH PADA MATRIKS POLINOMIAL
}

\author{
De wi Astuti, Helmi, Eka Wulan Ramadhani
}

\section{INTISARI}

\begin{abstract}
Dalam teori matriks dikenal suatu bentuk kanonik Smith. Bentuk ini digunakan sebagai alternatifapabila suatu matriks tidak dapat didiagonalisasikan. Penelitian ini bertujuan untuk menganalisis bentuk kanonik Smith, menyelidiki eksistensi bentuk kanonik Smith dan menyelidiki ketunggalan bentuk kanonik Smith pada matriks polinomial atas real. Bentuk kanonik Smith merupakan matriks hasil reduksi dari sebarang matriks polinomial atas real yang bentuknya mendekati bentuk matriks diagonal, dengan elemen-elemen pada diagonal utamanya $f_{1}(x), f_{2}(x), \ldots, f_{r}(x)$ merupakan monik dan $f_{k}(x) \mid f_{k+1}(x)$ untuk $k=1,2, \ldots, r-1$. Setiap matriks polinomial atas real yang diberikan adalah ekuivalen dengan matriks kanonik Smith yang terbentuk. Bentuk kanonik Smith pada umumnya dapat ditentukan dengan menggunakan transformasi baris dan kolom elementer. Pada matriks polinomial atas real, bentuk kanonik Smith dibentuk dengan menentukan elemen yang memiliki derajat terendah sebagai elemen satu utamanya yang kemudian diubah menjadi suatu monik serta membagi elemen lainnya. Selain dengan meng gunakan transformasi elemen ter, bentuk kanonik Smith juga dapat ditentukan melalui pembagi determinan yang merupakan pembagi persekutuan terbesar dari minor-minor bujur sangkar pada matriks. Dengan menerapkan hubungan antara faktor invarian dan pembagi determinan, maka diperoleh elemen-elemen pada diagonal utama suatu matriks kanonik Smith. Dari penelitian yang dilakukan dapat diketahui bahwa bentuk kanonik Smith dapat secara tunggal ditentukan dari suatu matriks polinomial atas real yang diberikan.
\end{abstract}

Kata Kunci: bentuk kanonik Smith, matriks polinomial, transformasi elementer, pembagi determinan

\section{PENDAHULUAN}

Matriks merupakan himpunan entri-entri atau elemen-elemen yang tersusun dalam baris dan kolom serta diapit oleh dua kurung siku [1]. Ukuran sebuah matriks dinyatakan dalam ordo yang dijelaskan dengan menyatakan banyaknya baris (horizontal) dan banyaknya kolom (vertikal) yang terdapat dalam matriks tersebut [2]. Berdasarkan ukuran dan bentuk matriks yang berbeda-beda maka matriks memiliki beberapa jenis diantaranya matriks bujur sangkar, matriks identitas dan matriks diagonal.

Di dalam sebuah matriks terdapat sebuah istilah diagonalisasi matriks yaitu sebuah proses pembentukan suatu matriks menjadi matriks diagonal dengan melibatkan nilai eigen dan vektor eigen. Suatu matriks bujur sangkar $\boldsymbol{A}$ dapat didiagonalisasi jika terdapat sebuah matriks nonsingular $\boldsymbol{P}$ sedemikian sehingga $\boldsymbol{P}^{\mathbf{- 1}} \boldsymbol{A P}$ adalah sebuah matriks diagonal, matriks $\boldsymbol{P}$ dikatakan mendiagonalisasi $\boldsymbol{A}$ [2]. Tidak semua matriks bujur sangkar dapat didiagonalisasi tergantung dari jumlah basis ruang eigen yang dimiliki. Jika matriks bujur sangkar berukuran $n$ dan basis ruang eigen yang bebas linear berjumlah $n$ juga maka matriks tersebut dapat didiagonalisasi, sedangkan jika basis ruang eigen jumlahnya kurang dari $n$ maka tidak dapat didiagonalisasi. Matriks yang tidak dapat didiagonalisasi ini dapat diubah ke bentuk kanonik yang bentuknya mendekati matriks diagonal [3]. Dalam teori matriks dikenal suatu bentuk kanonik matriks yaitu bentuk kanonik Smith.

Pada umumnya analisis pada matriks dilakukan hanya terbatas pada matriks konstan, tetapi pada kenyataannya terdapat juga masalah yang memunculkan sebuah matriks polinomial. Matriks polinomia 1 ini tersusun atas deret suku banyak dengan koefisien tertentu sebagai elemen-elemen matriks. Penelitian ini bertujuan untuk menganalisis bentuk kanonik Smith, menyelidiki eksistensi bentuk kanonik Smith dan menyelidiki ketunggalan bentuk kanonik Smith pada matriks polinomial atas $\mathbb{R}$. Matriks yang digunakan dalam penelitian ini yaitu matriks polinomial $\mathbb{R}$ yang berukuran $m \times n$. Proses pembentukan matriks polinomial menjadi bentuk kanonik Smith selain dengan menggunakan transformasi elementer, juga dapat ditentukan dengan reduksi menggunakan pembagi determinan. Untuk lebih jelasnya, proses pembentukan pembentukan kanonik Smith dapat dilihat pada Gambar 1. 


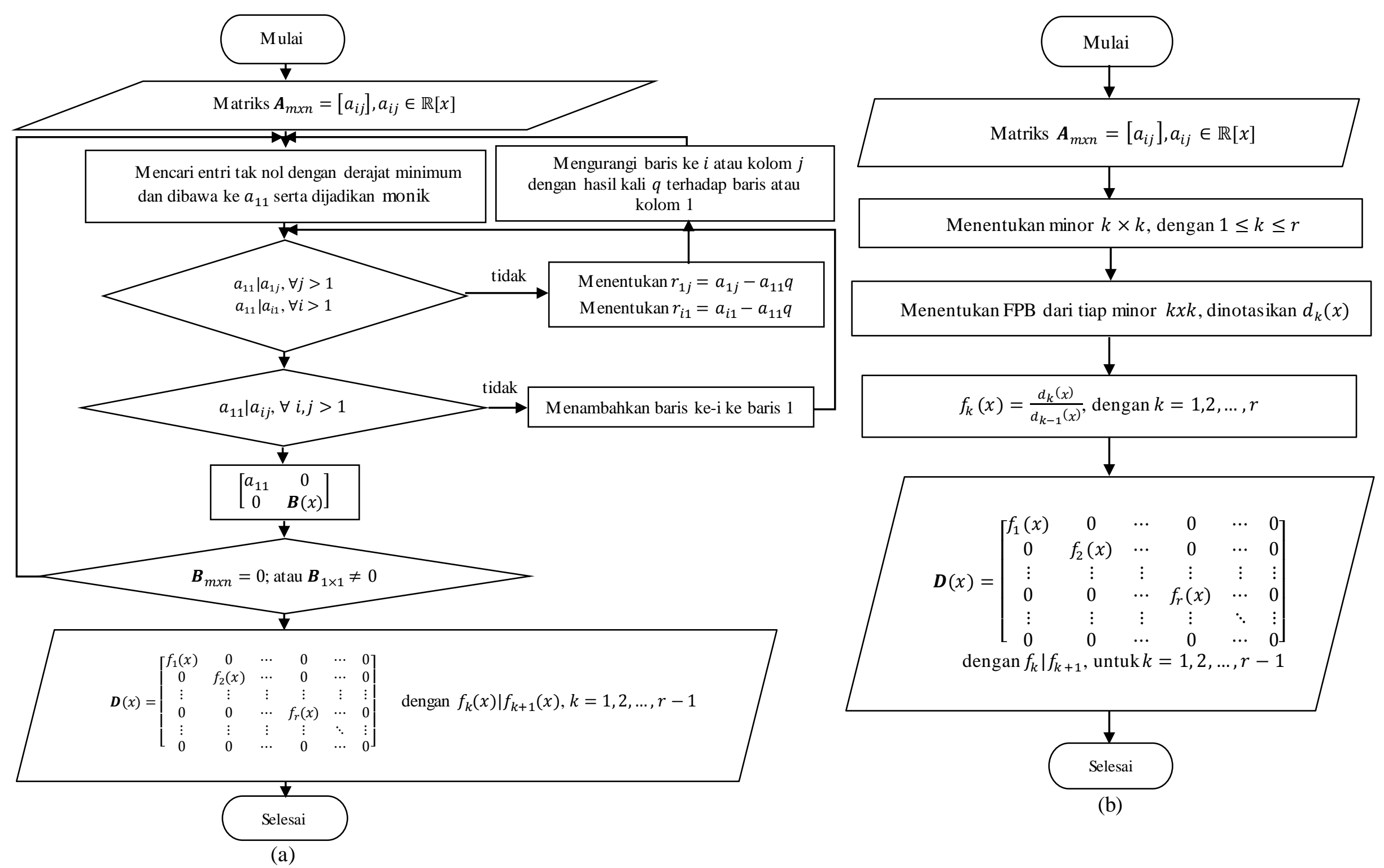

Gambar 1. (a) Bentuk kanonik Smith dengan transformasi elementer dan (b) bentuk kaonik Smith dengan pembagi determinan 
Pada Gambar 1 (a) proses pembentukan bentuk kanonik Smith dilakukan dengan menggunakan transformasi elementer, yaitu dengan menentukan elemen yang memiliki derajat terendah sebagai elemen satu utamanya yang kemudian diubah menjadi suatu monik serta membagi elemen lainnya. Elemen ini disimbolkan dengan $f_{1}$. Proses ini dilakukan secara berulang untuk mendapatkan elemenelemen $f_{2}, f_{3}, \ldots, f_{r}$. Sedangkan pada Gambar 1 (b) proses pembentukan bentuk kanonik Smith dilakukan dengan menentukan faktor persekutuan terbesar dari minor-minor bujur sangkar $k \times k$. Kemudian dengan menerapkan hubungan antara pembagi determinan dan faktor invarian maka diperoleh elemen-elemen $f_{1}, f_{2}, f_{3}, \ldots, f_{r}$. Dari kedua cara ini dapat dilihat bahwa proses pembentukan kanonik Smith seperti pada Gambar 1 (b) akan lebih efektif digunakan dibanding proses seperti pada Gambar 1 (a) apabila suatu matriks yang diberikan berukuran $m \times n$ dengan $m, n \leq 3$. Jika matriks yang diberikan berukuran $m \times n$ dengan $m, n>3$, maka sebaiknya menggunakan cara seperti pada Gambar 1 (a) karena proses seperti pada Gambar 1 (b) akan memerlukan waktu yang cukup panjang dalam mencari nilai minor-minor bujur sangkar $k \times k$.

\section{TRANSFORMASI ELEMENTER PADA MATRIKS POLINOMIAL}

Bentuk-bentuk transformasi elementer pada suatu matriks polinomial dapat dilihat dalam Definisi 1 sebagai berikut.

Definisi 1 [4] Suatu transformasi elementer pada suatu matriks $\boldsymbol{A}(x)$ atas $\mathbb{R}[x]$ diartikan:

(1) Penukaran baris ke-i dan baris ke-j yang dinyatakan oleh $H_{i j}$, penukaran kolom ke-i dan kolom ke-j dinyatakan oleh $K_{i j}$.

(2) Perkalian baris ke-i oleh suatu konstanta $k$ tak nol yang dinyatakan oleh $H_{i}(k)$, perkalian kolom ke-i oleh suatu konstanta $k$ tak nol, dinyatakan oleh $K_{i}(k)$.

(3) Penambahan pada baris ke-i dengan hasil kali $f(x)$ dan baris ke-j dinyatakan oleh $H_{i j}(f(x))$, penambahan pada kolom ke-i dengan hasil kali $f(x)$ dan kolom ke-j dinyatakan oleh $K_{i j}(f(x))$.

Contoh 2 Diberikan matriks

$$
\boldsymbol{A}(x)=\left[\begin{array}{cc}
1+x^{2} & x \\
x & 1+x
\end{array}\right]
$$

Dengan menerapkan transformasi $H_{12}, K_{2}(2)$, dan $H_{12}(-x)$ pada matriks $\boldsymbol{A}(x)$, maka diperoleh

$$
H_{12}=\left[\begin{array}{cc}
x & 1+x \\
1+x^{2} & x
\end{array}\right] \quad K_{2}(2)=\left[\begin{array}{cc}
1+x^{2} & 2 x \\
x & 2+2 x
\end{array}\right] \quad H_{12}(-x)=\left[\begin{array}{cc}
1 & -x^{2} \\
x & 1+x
\end{array}\right]
$$

\section{MATRIKS ELEMENTER}

Sebuah matriks $n \times n$ dinamakan matriks elementer jika matriks tersebut dapat diperoleh dari matriks satuan (identitas) $n \times n$ yakni $\boldsymbol{I}_{n}$ dengan melakukan sebuah transformasi baris atau kolom elementer tunggal [2]. Untuk lebih jelasnya, diberikan contoh matriks elementer yang dapat dilihat pada Contoh 3 berikut ini.

Contoh 3 Matriks elementer yang diperoleh dari $\boldsymbol{I}_{3}=\left[\begin{array}{lll}1 & 0 & 0 \\ 0 & 1 & 0 \\ 0 & 0 & 1\end{array}\right]$ adalah

$$
H_{3}(k)=\left[\begin{array}{ccc}
1 & 0 & 0 \\
0 & 1 & 0 \\
0 & 0 & k
\end{array}\right]=K_{3}(k), \quad H_{23}(k)=\left[\begin{array}{ccc}
1 & 0 & 0 \\
0 & 1 & k \\
0 & 0 & 1
\end{array}\right]=K_{32}(k)
$$

\section{EKUIVALENSI MATRIKS}

Diberikan $\boldsymbol{A}, \boldsymbol{B} \in \boldsymbol{M}_{m \times n}$ matriks $\boldsymbol{A}$ dan $\boldsymbol{B}$ disebut ekuivalen (ditulis $\boldsymbol{A} \sim \boldsymbol{B}$ ) jika terdapat matriks $\boldsymbol{P} \in \boldsymbol{M}_{m \times m}$ dan $\boldsymbol{Q} \in \boldsymbol{M}_{n \times n}$. Matriks $\boldsymbol{P}$ dan $\boldsymbol{Q}$ ini merupakan hasil kali matriks-matriks baris dan kolom elementer yang didapat dari transformasi-transformasi baris dan kolom elementer untuk mereduksi $\boldsymbol{A}$ 
menjadi $\boldsymbol{B}$ dinyatakan sebagai $\boldsymbol{H}_{1}, \boldsymbol{H}_{2}, \ldots, \boldsymbol{H}_{s} ; \boldsymbol{K}_{1}, \boldsymbol{K}_{2}, \ldots, \boldsymbol{K}_{t}$. Matriks $H_{1}$ adalah matriks hasil transformasi baris yang pertama, $H_{2}$ adalah matriks hasil transformasi baris yang kedua dan seterusnya, sedangkan $K_{1}$ adalah matriks hasil transformasi kolom yang pertama, $K_{2}$ adalah matriks hasil transformasi kolom yang kedua dan seterusnya. Sedemikian sehingga memenuhi [4]

di mana

$$
H_{S} \cdot \ldots \cdot H_{2} \cdot H_{1} \cdot A \cdot K_{1} \cdot K_{2} \cdot \ldots \cdot K_{t}=\boldsymbol{P A Q}=\boldsymbol{B},
$$

$$
\boldsymbol{P}=H_{s} \cdot \ldots \cdot H_{2} \cdot H_{1} \text { dan } \boldsymbol{Q}=K_{1} \cdot K_{2} \cdot \ldots \cdot K_{t} .
$$

\section{BENTUK KANONIK SUATU MATRIKS}

Bentuk kanonik suatu matriks merupakan matriks yang diperoleh dengan menggunakan transformasi elementer pada sebarang matriks $\boldsymbol{A}$ yang memiliki rank $\mathrm{r}>0$ dan direduksi ke salah satu dari bentuk berikut

$$
\left[\boldsymbol{I}_{r}\right], \quad\left[\begin{array}{cc}
\boldsymbol{I}_{\mathrm{r}} & 0 \\
0 & 0
\end{array}\right], \quad\left[\begin{array}{ll}
\boldsymbol{I}_{r} & \mathbf{0}
\end{array}\right], \quad\left[\begin{array}{c}
\boldsymbol{I}_{\mathrm{r}} \\
0
\end{array}\right] .
$$

Matriks nol adalah bentuk kanonik dari matriks nol itu sendiri [4].

\section{PEMBAGI DETERMINAN}

Setiap matriks memiliki satu atau beberapa submatriks. Submatriks dari sebuah matriks $\boldsymbol{A}$ adalah matriks $\boldsymbol{A}$ itu sendiri dan matriks-matriks yang diperoleh dengan menghilangkan salah satu atau lebih vektor-vektor baris dan/atau vektor-vektor kolom dari matriks $\boldsymbol{A}$ [5]. Minor-minor dari suatu matriks diperoleh dengan menentukan nilai determinan dari submatriks yang telah dibentuk. Pada matriks polinomial, pembagi persekutuan terbesar dari minor-minor yang terbentuk disebut pembagi determinan. Untuk lebih jelasnya diberikan definisi mengenai pembagi determinan pada sebuahmatriks, yaitu dapat dilihat pada Definisi 4 sebagai berikut:

Definisi 4 [6] Diberikan $\boldsymbol{A}(x) \in \boldsymbol{M}_{m x n}(\mathbb{R}[x])$, kemudian untuk $1 \leq k \leq r$ diberikan $d_{k}(\boldsymbol{A})$ yang didefinisikan sebagai pembagi determinan ke-k dari $\boldsymbol{A}(x)$ yang merupakan pembagi persekutuan terbesar $(F P B)$ dari semua minor $k x k$ dari $\boldsymbol{A}(x)$.

Dalam pembagi determinan terdapat hubungan antara pembagi determinan yang satu dengan yang lainnya untuk $1 \leq k \leq r$ yang akan dijelaskan dalam Teorema 5 berikut.

Teorema 5 [6] Diberikan $\boldsymbol{A}(x) \in \boldsymbol{M}_{m x n}(\mathbb{R}[x])$, untuk $1 \leq k \leq r$ didapat $d_{k}(\boldsymbol{A}) \neq 0 . d_{k}(\boldsymbol{A})$ juga membagi $_{k+1}(\boldsymbol{A})$ untuk $1 \leq k \leq r-1$.

Bukti:

Dimisalkan matriks $\boldsymbol{A}(x)$ memiliki rank $r$, berarti terdapat sebuah minor tak-nol $r \times r$ dan karenanya $d_{r}(\boldsymbol{A}) \neq 0$. Karena setiap minor $r \times r$ adalah kombinasi linear dari minor $(r-1) \times(r-$ 1) dari $\boldsymbol{A}(x)$, maka beberapa minor $(r-1) \times(r-1)$ dari $\boldsymbol{A}(x)$ juga tak nol dan akibatnya $d_{r-1}(A) \neq$ 0 . Berdasarkan Definisi 7 diketahui bahwa $d_{r-1}(\boldsymbol{A})$ merupakan pembagi persekutuan terbesar dari semua minor ukuran $r-1$ atau dengan kata lain $d_{r-1}(A)$ membagi setiap minor dari ukuran $r-1$, akibatnya $d_{r-1}(\boldsymbol{A})$ juga membagi setiap minor pada ukuran $r$. Oleh karena itu $d_{r-1}(\boldsymbol{A})$ membagi $d_{r}(\boldsymbol{A})$ yang merupakan pembagi persekutuan terbesar dari semua minor ukuran $r$. Pernyataan ini dapat diulangi dengan mengganti $r$ dengan $r-1$ dan seterusnya sehingga diperoleh $d_{k}(\boldsymbol{A})$ juga membagi $d_{k+1}(\boldsymbol{A})$ untuk $1 \leq k \leq r-1$.

Berikut ini diberikan suatu teorema yang menyatakan dua buah matriks yang ekuivalen akan mempunyai pembagi determinan yang sama.

Teorema 6 [6] Diberikan $\boldsymbol{A}(x), \boldsymbol{B}(x) \in \boldsymbol{M}_{m \times n}((\mathbb{R}[x])$. Jika matriks $\boldsymbol{A}(x)$ ekuivalen dengan matriks $\boldsymbol{B}(x)$, $\operatorname{makad}_{k}(\boldsymbol{A})=d_{k}(\boldsymbol{B})$ untuk $1 \leq k \leq r$. 


\section{BENTUK KANONIK SMITH}

Bentuk kanonik Smith merupakan bentuk matriks yang bentuknya mendekati bentuk matriks diagonal, namun memiliki syarat-syarat tertentu yang menyatakan suatu matriks dapat dikatakan bentuk kanonik Smith. Berikut ini akan diberikan suatu definisi bentuk kanonik Smith dan faktor invarian yang dapat dilihat pada Definisi 7 dan Definisi 8.

Definisi 7 [7] Diberikan matriks $\boldsymbol{A}(x) \in \boldsymbol{M}_{m \times n}(\mathbb{R}[x])$ dengan $\operatorname{rank} \boldsymbol{A}(x)=r, r \leq \min \{m, n\}$. Matriks dengan bentuk

$$
\boldsymbol{D}(x)=\left[\begin{array}{cccccc}
f_{1}(x) & 0 & \cdots & 0 & \cdots & 0 \\
0 & f_{2}(x) & \cdots & 0 & \cdots & 0 \\
\vdots & \vdots & \vdots & \vdots & \vdots & \vdots \\
0 & 0 & \cdots & f_{r}(x) & \cdots & 0 \\
\vdots & \vdots & \vdots & \vdots & \ddots & \vdots \\
0 & 0 & \cdots & 0 & \cdots & 0
\end{array}\right]
$$

disebut bentuk kanonik Smith, jika matriks $\boldsymbol{A}(x)$ ekuivalen dengan matriks $\boldsymbol{D}(x)$ dan untuk setiap $f_{1}(x), f_{2}(x), \ldots, f_{r}(x) \in \mathbb{R}[x]$ adalah monik dan $f_{k}(x) \mid f_{k+1}(x)$ untuk $k=1,2, \ldots, r-1$.

Definisi 8 [4] Polinomial-polinomial $f_{1}(x), f_{2}(x), \ldots, f_{r}(x)$ pada diagonal bentuk kanonik Smith dari matriks $\boldsymbol{A}(x)$ disebut faktor-faktor invarian dari matriks $\boldsymbol{A}(x)$.

Bentuk kanonik Smith dapat ditentukan dengan menggunakan transformasi elementer dari sebuah matriks polinomial yang diberikan seperti dalam Teorema 9 berikut.

Teorema 9 [4] Setiap matriks polinomial $\boldsymbol{A}(x) \in \boldsymbol{M}_{m \times n}(\mathbb{R}[x])$ dengan rank $r$ dapat direduksi oleh transformasi elementer ke bentuk kanonik Smith.

Contoh 10 Reduksi matriks berikut ke bentuk kanonik Smith dengan metode transformasi elementer.

Penyelesaian:

$$
\boldsymbol{A}(x)=\left[\begin{array}{ccc}
x^{2}+1 & x^{3}+x & 2 x^{3}-x^{2}+x \\
x-1 & x^{2}+1 & x^{2}-2 x+1 \\
x^{2} & x^{3} & 2 x^{3}-x^{2}+1
\end{array}\right]
$$

Langkah pertama menentukan elemen dengan derajat terkecil dari matriks $\boldsymbol{A}(x)$. Dipilih elemen $a_{21}$ dan dengan penukaran baris- 2 ke baris- 1 elemen tersebut dibawa ke $a_{11}$, diperoleh

$$
\left[\begin{array}{ccc}
x-1 & x^{2}+1 & x^{2}-2 x+1 \\
x^{2}+1 & x^{3}+x & 2 x^{3}-x^{2}+x \\
x^{2} & x^{3} & 2 x^{3}-x^{2}+1
\end{array}\right]
$$

Selanjutnya karena elemen $a_{31} \nmid a_{11}$, maka dengan mengurangi elemen pada baris-3 terhadap hasil kali $(x+1)$ dan elemen pada baris- 1 diperoleh

$$
\left[\begin{array}{ccc}
x-1 & x^{2}+1 & x^{2}-2 x+1 \\
x^{2}+1 & x^{3}+x & 2 x^{3}-x^{2}+x \\
1 & -x^{2}-x-1 & x^{3}+x
\end{array}\right]
$$

Kemudian dengan penukaran baris-3 ke baris-1 diperoleh $a_{11}$ yang baru

$$
\left[\begin{array}{ccc}
1 & -x^{2}-x-1 & x^{3}+x \\
x^{2}+1 & x^{3}+x & 2 x^{3}-x^{2}+x \\
x-1 & x^{2}+1 & x^{2}-2 x+1
\end{array}\right]
$$

Karena $a_{11}$ dapat membagi setiap elemen di $\boldsymbol{A}(x)$, maka elemen pada baris dan kolom pertama selain $a_{11}$ dapat diubah menjadi 0

$$
\left[\begin{array}{ccc}
1 & 0 & 0 \\
0 & x^{4}+2 x^{3}+2 x^{2}+2 x+1 & -x^{5}-x^{2} \\
0 & x^{3}+x^{2} & -x^{4}+x^{3}-x+1
\end{array}\right]=\left[\begin{array}{cc}
1 & 0 \\
0 & \boldsymbol{B}(x)
\end{array}\right]
$$


Selanjutnya menentukan elemen dengan derajat terkecil dari $\boldsymbol{B}(x)$ dan dibawa ke $a_{11}$ sehingga diperoleh

$$
\left[\begin{array}{ccc}
1 & 0 & 0 \\
0 & x^{3}+x^{2} & -x^{4}+x^{3}-x+1 \\
0 & x^{4}+2 x^{3}+2 x^{2}+2 x+1 & -x^{5}-x^{2}
\end{array}\right]
$$

Karena elemen $a_{21} \nmid a_{11}$ di $\boldsymbol{B}(x)$, maka dengan mengurangi elemen pada baris- 2 terhadap hasil kali $(x+1)$ dengan elemen pada baris pertama di $\boldsymbol{B}(x)$ diperoleh

$$
\left[\begin{array}{ccc}
1 & 0 & 0 \\
0 & x^{3}+x^{2} & -x^{4}+x^{3}-x+1 \\
0 & x^{2}+2 x+1 & -x^{3}-1
\end{array}\right]
$$

Selanjutnya melakukan penukaran baris-2 ke baris-1 untuk memperoleh $a_{11}$ yang baru pada $\boldsymbol{B}(x)$

$$
\left[\begin{array}{ccc}
1 & 0 & 0 \\
0 & x^{2}+2 x+1 & -x^{3}-1 \\
0 & x^{3}+x^{2} & -x^{4}+x^{3}-x+1
\end{array}\right]
$$

Karena elemen $a_{21} \nmid a_{11}$ di $\boldsymbol{B}(x)$ kemudian dengan mengurangi elemen pada baris-2 terhadap hasil kali $(x-1)$ dengan elemen pada baris-1 di $\boldsymbol{B}(x)$ diperoleh

$$
\left[\begin{array}{ccc}
1 & 0 & 0 \\
0 & x^{2}+2 x+1 & -x^{3}-1 \\
0 & x+1 & 0
\end{array}\right]
$$

Selanjutnya dengan penukaran baris-2 ke baris-1 diperoleh $a_{11}$ yang baru pada $\boldsymbol{B}(x)$

$$
\left[\begin{array}{ccc}
1 & 0 & 0 \\
0 & x+1 & 0 \\
0 & x^{2}+2 x+1 & -x^{3}-1
\end{array}\right]
$$

Dari hasil transformasi di atas dapat diketahui bahwa $a_{11}$ pada $\boldsymbol{B}(x)$ dapat membagi elemen pada $\boldsymbol{B}(x)$ lainnya, sehingga elemen pada baris dan kolom pertama selain $a_{11}$ pada $\boldsymbol{B}(x)$ dapat diubah menjadi 0

$$
\left[\begin{array}{ccc}
1 & 0 & 0 \\
0 & x+1 & 0 \\
0 & 0 & x^{3}+1
\end{array}\right]=D(x)
$$

Berdasarkan hasil reduksi dari matriks $\boldsymbol{A}(x)$ diperoleh matriks $\boldsymbol{D}(x)$ yang merupakan bentuk kanonik Smith dengan nilai faktor invarian $f_{1}(x)=1, f_{2}(x)=x+1, f_{3}(x)=x^{3}+1$ adalah monik dan $f_{k}(x) \mid f_{k+1}(x)$ dengan $k=1,2$.

\section{KETUNGGALAN BENTUK KANONIK SMITH}

Berikut ini diberikan sebuah teorema yang menyatakan bahwa sebarang matriks $\boldsymbol{A}(x)$ hanya dapat membentuk sebuah bentuk kanonik Smith $(\boldsymbol{D}(x))$.

Teore ma 11 [4] Matriks $\boldsymbol{D}(x)$ yang merupakan bentuk kanonik Smith dapat secara tunggal ditentukan oleh matriks $\boldsymbol{A}(x)$ yang diberikan.

Bukti:

Diberikan matriks $\boldsymbol{A}(x) \in \boldsymbol{M}_{m \times n}(\mathbb{R}[x])$. Kemudian diasumsikan $\boldsymbol{D}(x)$ dan $\boldsymbol{D}^{\prime}(x)$ merupakan dua buah bentuk kanonik Smith yang berbeda yang terbentuk dari matriks $\boldsymbol{A}(x)$, yaitu:

$$
\boldsymbol{D}(x)=\left[\begin{array}{cccccc}
f_{1}(x) & 0 & \cdots & 0 & \cdots & 0 \\
0 & f_{2}(x) & \cdots & 0 & \cdots & 0 \\
\vdots & \vdots & \vdots & \vdots & \vdots & \vdots \\
0 & 0 & \cdots & f_{r}(x) & \cdots & 0 \\
\vdots & \vdots & \vdots & \vdots & \ddots & \vdots \\
0 & 0 & \cdots & 0 & \cdots & 0
\end{array}\right] \text { dan }
$$




$$
\boldsymbol{D}^{\prime}(x)=\left[\begin{array}{cccccc}
f_{1}{ }^{\prime}(x) & 0 & \cdots & 0 & \cdots & 0 \\
0 & f_{2}{ }^{\prime}(x) & \cdots & 0 & \cdots & 0 \\
\vdots & \vdots & \vdots & \vdots & \vdots & \vdots \\
0 & 0 & \cdots & f_{r}{ }^{\prime}(x) & \cdots & 0 \\
\vdots & \vdots & \vdots & \vdots & \ddots & \vdots \\
0 & 0 & \cdots & 0 & \cdots & 0
\end{array}\right]
$$

Hal ini berarti $\boldsymbol{D}(x) \neq \boldsymbol{D}^{\prime}(x)$, berakibat

$$
f_{1}(x) \neq f_{1}^{\prime}(x), f_{2}(x) \neq f_{2}^{\prime}(x), \ldots, f_{r}(x) \neq f_{r}^{\prime}(x) .
$$

Karena dalam $\boldsymbol{D}(x)$ tiap $f_{k}(x) \mid f_{k+1}(x)$ dengan $k=1,2, \ldots, r-1$, maka pembagi persekutuan terbesar semua minor bujur sangkar $k \times k$ dari $\boldsymbol{D}(x)$ adalah

$$
d_{k}(D(x))=f_{1}(x) \cdot f_{2}(x) \cdot \ldots \cdot f_{k}(x), \quad k=1,2, \ldots, r .
$$

Sekarang dapat diketahui $d_{1}(x)=f_{1}(x), d_{2}(x)=f_{1}(x) \cdot f_{2}(x)$ dan seterusnya. Sehingga secara umum jika didefinisikan $d_{0}(x)=1$, maka

$$
f_{k}(x)=\frac{d_{k}(x)}{d_{k-1}(x)}, \quad k=1,2, \ldots, r .
$$

Demikian pula dengan $\boldsymbol{D}^{\prime}(x)$, karena tiap $f_{k}^{\prime}(x) \mid f_{k+1}^{\prime}(x)$ dengan $k=1,2, \ldots, r-1$, maka pembagi persekutuan terbesar semua minor bujur sangkar $k \times k$ dari $\boldsymbol{D}(x)$ adalah

$$
d_{k}^{\prime}(D(x))=f_{1}^{\prime}(x) \cdot f_{2}^{\prime}(x) \cdot \ldots \cdot f_{k}^{\prime}(x), \quad k=1,2, \ldots, r .
$$

Sekarang dapat diketahui $d_{1}^{\prime}(x)=f_{1}^{\prime}(x), d_{2}^{\prime}(x)=f_{1}^{\prime}(x) . f_{2}^{\prime}(x)$ dan seterusnya. Sehingga secara umum jika didefinisikan $d_{0}^{\prime}(x)=1$, maka

$$
f_{k}^{\prime}(x)=\frac{d_{k}^{\prime}(x)}{d_{k-1}^{\prime}(x)}, \quad k=1,2, \ldots, r .
$$

Dari definisi bentuk kanonik Smith diketahui bahwa matriks $\boldsymbol{A}(x) \sim \boldsymbol{D}(x)$ dan $\boldsymbol{A}(x) \sim \boldsymbol{D}^{\prime}(x)$, akibatnya berdasarkan Teorema 6 yaitu pembagi persekutuan terbesar semua minor bujur sangkar $k \times k$ dari $\boldsymbol{A}(x)$ adalah pembagi persekutuan terbesar dari semua minor bujur sangkar $k \times k$ dari $\boldsymbol{D}(x)$ dan juga pembagi persekutuan terbesar dari semua minor bujur sangkar $k \times k$ dari $\boldsymbol{D}^{\prime}(x)$. Dapat dituliskan sebagaiberikut:

$$
\begin{aligned}
& d_{k}(\boldsymbol{A}(x))=d_{k}(\boldsymbol{D}(x)) \\
& d_{k}(\boldsymbol{A}(x))=d_{k}\left(\boldsymbol{D}^{\prime}(x)\right) .
\end{aligned}
$$

Dari Persamaan 2 dan Persamaan 3, maka diperoleh $d_{k}(\boldsymbol{D}(x))=d_{k}\left(\boldsymbol{D}^{\prime}(x)\right)$ atau dengan kata lain $f_{1}(x) \cdot f_{2}(x) \cdot \ldots \cdot f_{k}(x)=f_{1}^{\prime}(x) \cdot f_{2}^{\prime}(x) \cdot \ldots \cdot f_{k}^{\prime}(x)$. Sehingga

$$
f_{1}(x)=f_{1}^{\prime}(x), f_{2}(x)=f_{2}^{\prime}(x), \ldots, f_{r}(x)=f_{r}^{\prime}(x)
$$

Berdasarkan hal tersebut, maka terjadi kontradiksi dengan pengandaian di awal $f_{1}(x) \neq f_{1}^{\prime}(x), f_{2}(x) \neq$ $f_{2}^{\prime}(x), \ldots, f_{r}(x) \neq f_{r}^{\prime}(x)$. Dengan demikian didapat $\boldsymbol{D}(x)=\boldsymbol{D}^{\prime}(x)$, sehingga dapat disimpulkan bahwa bentuk kanonik Smith dapat secara tunggal ditentukan oleh matriks $\boldsymbol{A}(x)$ yang diberikan.

\section{B ENTUK KANONIK SMITH DENGAN PEMBAGI DETERMINAN}

Berdasarkan Teorema 11, maka dapat diketahui bahwa sebarang matriks $\boldsymbol{A}(x)$ dapat ditentukan bentuk kanonik Smith-nya $(\boldsymbol{D}(x))$ dengan menggunakan pembagi determinan. Langkah-langkah yang dilakukan yaitu pertama-tama mengumpulkan data berupa matriks $\boldsymbol{A}_{m x n}(x)$, dalam penelitian ini khususnya berupa matriks polinomial atas $\mathbb{R}$. Kemudian menentukan semua minor $k \times k$ untuk $1 \leq$ $k \leq r$ dari matriks tersebut. Setelah didapat minor $k \times k$, sehingga dapat ditentukan pembagi persekutuan terbesar dari masing-masing minor $k \times k$, nilai ini di lambangkan dengan $d_{k}(x)$. Dengan menerapkan $f_{k}(x)=\frac{d_{k}(x)}{d_{k-1}(x)} \quad$ untuk $1 \leq k \leq r$ sehingga diperoleh $f_{1}(x), f_{2}(x), \ldots, f_{k}(x)$ yang merupakan nilai-nilai faktor invarian. Dengan demikian matriks $\boldsymbol{A}(x)$ dapat dibentuk menjadi suatu bentuk kanonik Smith seperti pada persamaan 1. 
Contoh 12 Reduksi matriks berikut ke bentuk kanonik Smith dengan menerapkan definisi pembagi determinan dan hubungannya dengan faktor invariant.

$$
\boldsymbol{A}(x)=\left[\begin{array}{ccc}
x^{2}+1 & x^{3}+x & 2 x^{3}-x^{2}+x \\
x-1 & x^{2}+1 & x^{2}-2 x+1 \\
x^{2} & x^{3} & 2 x^{3}-x^{2}+1
\end{array}\right]
$$

\section{Penyelesaian:}

Dengan menggunakan pembagi determinan, bentuk kanonik Smith dapat diperoleh melalui langkahlangkah sebagai berikut.

1. Menentukan setiap minor $k \times k$ dari matriks $\boldsymbol{A}(x)$.

Untuk minor-minor $1 \times 1$ diperoleh

$x^{2}+1, x^{3}+x, 2 x^{3}-x^{2}+x, x-1, x^{2}+1, x^{2}-2 x+1, x^{2}, x^{3}$, dan $2 x^{3}-x^{2}+1$.

Untuk minor-minor $2 \times 2$ dari matriks $\boldsymbol{A}(x)$ diperoleh

$M_{11}=x^{5}+x^{4}+x^{3}+1=(x+1)\left(x^{4}+x^{2}-x+1\right)$,

$M_{12}=x^{4}-x^{3}+x-1=(x-1)(x+1)\left(x^{2}-x+1\right)$,

$M_{13}=-x^{3}-x^{2}=-x^{2}(x+1)$,

$M_{21}=x^{4}+x=x(x+1)\left(x^{2}-x+1\right)$,

$M_{22}=x^{3}+1=(x+1)\left(x^{2}-x+1\right)$,

$M_{23}=0$,

$M_{31}=-x^{5}-x^{4}-x^{3}-x^{2}=-x^{2}(x+1)\left(x^{2}+1\right)$,

$M_{32}=-x^{4}+x^{3}-x+1=-(x-1)(x+1)\left(x^{2}-x+1\right)$,

$M_{33}=x^{3}+x^{2}+x+1=(x+1)\left(x^{2}+1\right)$.

Untuk minor $3 \times 3$ dari matriks $\boldsymbol{A}(x)$ diperoleh $x^{4}+x^{3}+x+1$ yang merupakan determinan dari matriks $\boldsymbol{A}(x)$.

2. Menentukan pembagi persekutuan terbesar dariminor-minor $k \times k$ yang telah diperoleh.

Dari minor-minor $1 \times 1,2 \times 2$, dan $3 \times 3$ yang diperoleh, maka dapat ditentukan pembagi persekutuan terbesar dari masing-masing minor yaitu $d_{1}(x)=1, d_{2}(x)=x+1$ dan $d_{3}(x)=$ $\operatorname{det}(\boldsymbol{A}(x))=x^{4}+x^{3}+x+1$.

3. Menentukan $f_{1}(x), f_{2}(x)$, dan $f_{3}(x)$.

Dengan menggunakan hubungan antara pembagi determinan dengan invarian faktor matriks tersebut, diperoleh $f_{1}(x)=1, f_{2}(x)=\frac{d_{2}(x)}{d_{1}(x)}=x+1$, dan $f_{3}=\frac{d_{3}(x)}{d_{2}(x)}=x^{3}+1$.

Jadi bentuk kanonik Smith dari matriks $\boldsymbol{A}(x)$ adalah

$$
\boldsymbol{D}(x)=\left[\begin{array}{ccc}
1 & 0 & 0 \\
0 & x+1 & 0 \\
0 & 0 & x^{3}+1
\end{array}\right]
$$

Dari Contoh 10 dan Contoh 12 telah didapat matriks $\boldsymbol{D}(x)$ dengan nilai faktor invarian $f_{1}(x)=$ $1, f_{2}(x)=x+1, f_{3}(x)=x^{3}+1$ merupakan monik dan $f_{k}(x) \mid f_{k+1}(x)$ dengan $k=1,2$. Selanjutnya akan ditunjukkan bahwa matriks $\boldsymbol{A}(x)$ ekuivalen dengan matriks $\boldsymbol{D}(x)$. Terlebih dahulu akan dicari matrik $\boldsymbol{P}(x)$ dan $\boldsymbol{Q}(x)$ yang merupakan hasil kali matriks-matriks baris dan kolom elementer yang diperoleh dari $\boldsymbol{I}_{n}$ (matriks identitas) dengan melakukan transformasi baris dan kolom sesuai dengan transformasi-transformasi yang diberikan untuk mereduksi matriks $\boldsymbol{A}(x)$ menjadi matriks $\boldsymbol{D}(x)$, sebagai berikut:

$$
\begin{aligned}
\boldsymbol{P}(x)= & H_{3}(-1) \cdot H_{32}(-x-1) \cdot H_{32} \cdot H_{32}(-x+1) \cdot H_{32} \cdot H_{32}(-x-1) \cdot H_{32} \cdot H_{31}(-x+1) \cdot \\
& H_{21}\left(-x^{2}-1\right) \cdot H_{31} \cdot H_{31}(-x-1) \cdot H_{12}
\end{aligned}
$$




$$
\begin{aligned}
& =\left[\begin{array}{ccc}
1 & 0 & 0 \\
0 & 1 & 0 \\
0 & 0 & -1
\end{array}\right] \cdot\left[\begin{array}{ccc}
1 & 0 & 0 \\
0 & 1 & 0 \\
0 & -x-1 & 1
\end{array}\right] \cdot\left[\begin{array}{ccc}
1 & 0 & 0 \\
0 & 0 & 1 \\
0 & 1 & 0
\end{array}\right] \cdot\left[\begin{array}{ccc}
1 & 0 & 0 \\
0 & 1 & 0 \\
0 & -x+1 & 1
\end{array}\right] . \\
& {\left[\begin{array}{lll}
1 & 0 & 0 \\
0 & 0 & 1 \\
0 & 1 & 0
\end{array}\right] \cdot\left[\begin{array}{ccc}
1 & 0 & 0 \\
0 & 1 & 0 \\
0 & -x-1 & 1
\end{array}\right] \cdot\left[\begin{array}{ccc}
1 & 0 & 0 \\
0 & 0 & 1 \\
0 & 1 & 0
\end{array}\right] \cdot\left[\begin{array}{ccc}
1 & 0 & 0 \\
0 & 1 & 0 \\
-x+1 & 0 & 1
\end{array}\right] \text {. }} \\
& {\left[\begin{array}{ccc}
1 & 0 & 0 \\
-x^{2}-1 & 1 & 0 \\
0 & 0 & 1
\end{array}\right] \cdot\left[\begin{array}{lll}
0 & 0 & 1 \\
0 & 1 & 0 \\
1 & 0 & 0
\end{array}\right] \cdot\left[\begin{array}{ccc}
1 & 0 & 0 \\
0 & 1 & 0 \\
-x-1 & 0 & 1
\end{array}\right] \cdot\left[\begin{array}{lll}
0 & 1 & 0 \\
1 & 0 & 0 \\
0 & 0 & 1
\end{array}\right]} \\
& =\left[\begin{array}{ccc}
0 & -x-1 & 1 \\
-x+1 & 1 & x-1 \\
-x^{2} & 0 & x^{2}+1
\end{array}\right] \\
& \boldsymbol{Q}(x)=K_{21}\left(x^{2}+x+1\right) \cdot K_{31}\left(-x^{3}-x\right) \\
& =\left[\begin{array}{ccc}
1 & x^{2}+x+1 & 0 \\
0 & 1 & 0 \\
0 & 0 & 1
\end{array}\right] \cdot\left[\begin{array}{ccc}
1 & 0 & -x^{3}-x \\
0 & 1 & 0 \\
0 & 0 & 1
\end{array}\right]=\left[\begin{array}{ccc}
1 & x^{2}+x+1 & -x^{3}-x \\
0 & 1 & 0 \\
0 & 0 & 1
\end{array}\right],
\end{aligned}
$$

selanjutnya

$$
\begin{aligned}
\boldsymbol{P}(x) \boldsymbol{A}(x) \boldsymbol{Q}(x)= & {\left[\begin{array}{ccc}
0 & -x-1 & 1 \\
-x+1 & 1 & x-1 \\
-x^{2} & 0 & x^{2}+1
\end{array}\right] } \\
& {\left[\begin{array}{ccc}
x^{2}+1 & x^{3}+x & 2 x^{3}-x^{2}+x \\
x-1 & x^{2}+1 & x^{2}-2 x+1 \\
x^{2} & x^{3} & 2 x^{3}-x^{2}+1
\end{array}\right] . } \\
& {\left[\begin{array}{ccc}
1 & x^{2}+x+1 & -x^{3}-x \\
0 & 1 & 0 \\
0 & 0 & 1
\end{array}\right] } \\
= & {\left[\begin{array}{ccc}
1 & -x^{2}-x-1 & x^{3}+x \\
0 & x+1 & 0 \\
0 & 0 & x^{3}+1
\end{array}\right] \cdot\left[\begin{array}{ccc}
1 & x^{2}+x+1 & -x^{3}-x \\
0 & 1 & 0 \\
0 & 0 & 1
\end{array}\right] } \\
= & {\left[\begin{array}{ccc}
1 & 0 & 0 \\
0 & x+1 & 0 \\
0 & 0 & x^{3}+1
\end{array}\right]=\boldsymbol{D}(x) . }
\end{aligned}
$$

Karena $\boldsymbol{P}(x) \boldsymbol{A}(x) \boldsymbol{Q}(x)=\boldsymbol{D}(x)$, sehingga dapat ditunjukkan matriks $\boldsymbol{A}(x)$ ekuivalen dengan matriks $\boldsymbol{D}(x)$.

\section{PENUTUP}

Bentuk kanonik Smith merupakan matriks hasil reduksi dari sebarang matriks polinomial atas $\mathbb{R}$ yang bentuknya mendekati bentuk matriks diagonal, dengan elemen-elemen pada diagonal utamanya $f_{1}(x), f_{2}(x), \ldots, f_{r}(x) \in \mathbb{R}(x)$ merupakan monik dan $f_{k}(x) \mid f_{k+1}(x)$ untuk $k=1,2, \ldots, r-1$. Setiap matriks polinomial atas $\mathbb{R}$ yang diberikan adalah ekuivalen dengan matriks kanonik Smith yang terbentuk. Bentuk kanonik Smith pada umumnya dapat ditentukan dengan menggunakan transformasi baris dan kolom elementer. Pada matriks polinomial atas $\mathbb{R}$, bentuk kanonik Smith dibentuk dengan menentukan elemen yang memiliki derajat terendah sebagai elemen satu utamanya yang kemudian diubah menjadi suatu monik serta membagi elemen lainnya. Selain dengan menggunakan transformasi elementer, bentuk kanonik Smith juga dapat ditentukan melalui pembagi determinan yang merupakan pembagi persekutuan terbesar dari minor-minor bujur sangkar pada matriks. Dengan menerapkan hubungan antara faktor invarian dan pembagi determinan, maka diperoleh elemen-elemen pada diagonal utama suatu matriks kanonik Smith. Dari penelitian yang dilakukan dapat diketahui bahwa bentuk kanonik Smith dapat secara tunggal ditentukan dari suatu matriks polinomial atas $\mathbb{R}$ yang diberikan. 


\section{DAFTAR PUSTAKA}

[1] Imrona, M. Aljabar Linear Dasar. Jakarta: Erlangga; 2009.

[2] Anton, H. dan Rorres, C. Aljabar Linear Elementer Versi Aplikasi, Ed ke-8. Jakarta: Erlangga; 2004.

[3] Thresye. Penggunaan Bentuk Smith untuk Menentukan Bentuk Kanonik Matriks Normal dengan Entri-entri Bilangan Kompleks. Jurnal Matematika Murni dan Terapan. 2010;4(2):30-37.

[4] Ayres, F. Teoridan Soal-soal Matriks Versi S1/Metrik [ I.N. Susila, trans]. Jakarta:Erlangga; 1985.

[5] Purwanto, C. Matriks [Internet]. 2013 [cited 2018 September 8]. Available from: https:/plus.google.com/101134347067064493330/posts/gfaU1SB2MZZ

[6] Matthews, K.R. Linear Algebra Notes. Queensland: University of Queensland; 1991.

[7] Brown, W.C. Matrices Over Commutative Rings. NewYork: MarcelDekker; 1993.

DEWI ASTUTI : Jurusan Matematika FMIPA UNTAN, Pontianak dewi.astuti13579@gmail.com

HELMI : Jurusan Matematika FMIPA UNTAN, Pontianak helmi132205@yahoo.co.id

EKA WULAN RAMADHANI : Jurusan Matematika FMIPA UNTAN, Pontianak Ekawulan187@yahoo.co.id 